\title{
FRIENDLY FIRE: \\ THE MANDATORY MILITARY ANTHRAX VACCINATION PROGRAM
}

\author{
RANDALL D. KATZ
}

\begin{abstract}
INTRODUCTION
Your disobedience of the lawful order of a direct superior undermines the very essence of military good order and discipline. Your failure to live up to these standards cannot be condoned. ${ }^{1}$
\end{abstract}

From the time he was four years old, U.S. Air Force Major Sonnie Bates had a dream: to become a successful military pilot and serve his country. ${ }^{2}$ By all accounts, Major Bates accomplished his goal; he was an exceptional airman and highly decorated pilot who served his country for fourteen years. ${ }^{3} \mathrm{He}$ was an Air Force pilot instructor, flight examiner, safety program manager, instructor trainer, and chief of operations and analysis for the 436th Operations Group. ${ }^{4}$ Bates twice was awarded the Air Force Meritorious Service Medal and the Air Force Commendation Medal and received an Air Force Achievement Medal. ${ }^{5}$ His military career came to an abrupt end,

Copyright (C) 2001 by Randall D. Katz.

1. Official Reprimand of Major Sonnie Bates, quoted in Brad Knickerbocker, An Airman's Vaccination Becomes Test of Loyalty, CHRISTIAN SCI. MONITOR, Feb. 2, 2000, at 1. The author would like to sincerely thank Professor Scott Silliman, Director of the Duke University School of Law Center on Law, Ethics and National Security, for his assistance in critiquing this Note.

2. Id:; see also Susan Vela, Major Who Refused Vaccine Leaves Service, CincinnATI ENQUIRER, Mar. 31, 2000 (stating that Major Bates "lost [his] career for telling the truth"), available at $\mathrm{http} / / / \mathrm{enquirer} . \mathrm{com} / \mathrm{editions} / 2000 / 03 / 31 /$ loc_major_who_refused.html) (on file with the Duke Law Journal); Biography, Majorbates.com, at http://www.majorbates.com/bio_bates1. htm (last visited Apr. 2, 2001) (documenting Major Bates's career in the Air Force) (on file with the Duke Law Journal).

3. Biography, supra note 2.

4. Id.

5. Id. 
however, in March 2000. Major Bates refused to follow a direct order. ${ }^{6}$ The direct order was to take the anthrax vaccine. ${ }^{7}$

There is little controversy that anthrax poses a serious threat. Former Secretary of Defense William Cohen authorized the anthrax vaccination program because "anthrax poses a clear and present danger to our armed forces. It is the weapon of choice for germ warfare because it is easy to weaponize and is as lethal as the Ebola virus." Anthrax is produced by the bacteria Bacillus anthracis. Contamination can occur in three ways: through the skin, by ingestion, and by inhalation. ${ }^{9}$ Inhalation of anthrax, caused by the release of anthrax spores into the air, poses the largest threat because spores are highly lethal and easily manufactured. ${ }^{10}$ In fact, anthrax spores can be spread easily over a large area and can be stored effectively for decades. ${ }^{11} \mathrm{Al}-$ though everyone agrees that anthrax poses a serious threat, not everyone agrees that the anthrax vaccine is a safe and effective way to minimize that threat.

Sonnie Bates has become a symbol of the raging debate about the legality and effectiveness of the military's mandatory anthrax vaccination program (AVIP). ${ }^{12}$ Bates refused the vaccine based on his safety concerns. In a memorandum to the Air Force explaining his decision, Bates stated,

6. Knickerbocker, supra note 1 , at 1 .

7. Id.

8. Letter from William Cohen, Secretary of Defense, to Representative Christopher Shays et al., U.S. House of Representatives (Sept. 30, 1999), quoted in FOURTH REPORT BY THE COMMITTEE ON GOVERNMENT REFORM TOGETHER WITH DISSENTING AND SUPPLEMENTAL Views, The Department of Defense Anthrax Vaccine Immunization Program: UnProven Force Protection, H.R. Doc. No. 106-556, at 18 (2000), available at http://www.house.gov/reform/ns/reports/anthraxreport.pdf [hereinafter HOUSE REPORT].

9. Philip S. Brachman \& Arthur M. Friedlander, Anthrax, in VACCINES 629, 629-30 (Stanley A. Plotkin \& Walter A. Orenstein eds., 3d ed. 1999); see also Thomas V. Inglesby et al., Anthrax As a Biological Weapon: Medical and Public Health Management, 281 JAMA 1735, 1736 (1999) (describing the dangers of anthrax).

10. U.S. Dep't of Def., Anthrax: Questions and Answers on the Threat, at http://www. anthrax.osd.mil/Site_Files/qna/ THREAT.htm (last visited Apr. 2, 2001) [hereinafter U.S. Dep't of Def., Anthrax: Questions and Answers] (on file with the Duke Law Journal); U.S. Dep't of Def., Anthrax: The Threat, at http://www.anthrax.osd.mil/Site_Files/threat/threat_info.htm (last visited Apr. 15, 2001) [hereinafter U.S. Dep't of Def., Anthrax: The Threat] (on file with the Duke Law Journal).

11. U.S. Dep't of Def., Anthrax: The Threat, supra note 10.

12. Major Bates maintains an impressive Internet website that provides information on the anthrax vaccination program and resources for those considering submitting to inoculation. Majorbates.com, at http:// www.majorbates.com (last visited Apr. 2, 2001) (on file with the Duke Law Journal). 
I believe the anthrax vaccine is unsafe. It is linked to a large number of illnesses among people in my unit. Within a few weeks after I reported for duty I became aware that approximately 5\% of my squadron were suffering from unusual illnesses that resembled those described as Gulf War Illness. They all had two things in common; they all had the anthrax vaccine and were healthy before receiving the vaccine. ${ }^{13}$

Major Bates received a general discharge and lost his military pension and retirement benefits. ${ }^{14}$ Other service members have refused the vaccine because they believe it is unsafe, harmful, and ineffective. ${ }^{15}$ They distrust the government's research and recommendations. ${ }^{16}$ Major Bates is believed to be one of the highest-ranking military officials to refuse the vaccine. ${ }^{17}$ More recently, Captain John Buck, an Air Force physician, refused the anthrax vaccine. ${ }^{18}$ Captain Buck's case is noteworthy because he is the first military doctor to refuse the vaccine and because his refusal sends a message to service members. ${ }^{19}$

Secretary Cohen mandated anthrax vaccinations for the entire U.S. military in a May 18,1998 , memorandum. ${ }^{20}$ His directive spurred

13. Memorandum from Major Sonnie G. Bates, U.S. Air Force, to Brigadier General Starbuck, U.S. Air Force (Feb. 21, 2000), available at http://www.dallasnw.quik.com/cyberella/ Anthrax/Starbuck2.html. (last visited Apr. 2, 2001) (on file with the Duke Law Journal).

14. Id; see also Vela, supra note 2 (documenting the impact of the anthrax vaccine program on Major Bates's Air Force career).

15. Memorandum from Major Sonnie G. Bates to Brigadier General Starbuck, supra note 13; E-mail from Captain John Buck, U.S. Air Force, to Randall D. Katz (Feb. 21, 2001) (on file with the Duke Law Journal). The government does not release figures showing the number of soldiers who have refused the anthrax vaccine. Reports by the Associated Press estimate the number to be between 300 and 500. Deborah Funk, Air Force Physician Refuses to Submit to Anthrax Vaccine, AIR FORCE TIMES, Jan. 15, 2001, at 16.

16. However, through many public pronouncements and press conferences, the Department of Defense has concluded the vaccine is safe and effective. See, e.g., U.S. Dep't of Def., The Official DOD Website for the Anthrax Vaccine Immunization Program, at http://www. anthrax.osd.mil (last visited Apr. 2, 2001) (clicking on the "Test" button causes a pop-up window to appear, saying "Anthrax Kills, Vaccination Protects") (on file with the Duke Law Journal).

17. Vela, supra note 2.

18. Doctor Faces Court-Martial, AIR ForCE TIMES, Feb. 26, 2001, at 2; Funk, supra note 15; E-mail from Captain John Buck to Randall D. Katz, supra note 15.

19. Funk, supra note 15; E-mail from Captain John Buck to Randall D. Katz, supra note 15.

20. Memorandum from William S. Cohen, Secretary, U.S. Department of Defense, to the Secretaries of the Military Departments et al., U.S. Armed Forces (May 18, 1998), available at http://www.anthrax.osd.mil/Site_Files/policies/Policy_imp_files/POLICY_imp.htm (on file with the Duke Law Journal). On December 15, 1997, Secretary Cohen approved the program after a two-year review depending on four factors: (1) supplemental testing to assure sterility, safety, 
congressional hearings and disputes as to the legality of ordering soldiers to take the vaccine. These hearings, held by the Subcommittee on National Security, Veterans Affairs, and International Relations of the House Government Reform Committee, have been highly critical of AVIP. ${ }^{21}$ The media report that a substantial number of military personnel, especially reservists, are leaving the armed forces because they do not want to be vaccinated. ${ }^{22}$

The refusal of Major Bates to be vaccinated and the national attention his case garnered raise fundamental questions about the validity of military orders, informed consent for experimental vaccines, and medical ethics. This Note explores these issues, particularly the question whether a commander can require a service member to submit to an anthrax vaccination. This analysis necessarily involves legal, policy, and medical questions. Part I examines anthrax and the threat it poses. Part II explores the medical controversy surrounding the vaccine. Part III discusses the legal issues concerning orders to take the vaccine and includes an examination of the cases addressing the legality of disobeying an order. Finally, Part IV analyzes whether an order to take the anthrax vaccine is legal and concludes that such a direct order is illegal under federal law.

\footnotetext{
potency, and purity of the vaccine stockpile; (2) implementation of a system for fully tracking anthrax immunizations; (3) approval of operational plans to administer the vaccine and communications plans to inform military person; and (4) review of medical aspects of the program by an independent expert. $I d$. In issuing the final May 18, 1998, order, Secretary Cohen stated "all conditions for implementing the anthrax vaccination program for the total force have now been met." Id.

21. HOUSE REPORT, supra note 8 , at $1-4$.

22. Id. at 14 (reporting that "up to $30 \%$ of some units would resign or seek to transfer due to the anthrax program"); Thomas E. Ricks, Anthrax Shots Cause Military Exodus; Many Leaving Reserves, Guard Cite Pentagon Policy, GAO Says, WASH. Post, Oct. 11, 2000, at A29 (stating that the GAO Report deems "unhappiness with the mandatory anthrax program [as] the top reason" pilots and other air crew members have left the Guard and Reserves over the past two years); Jamie McIntyre, Congressional Report Says Anthrax Vaccine Large Part of Air Force Exodus, CNN.com, Oct. 11, 2000, at http://www.cnn.com/2000/US/10/11/anthrax.military/ (citing GAO report claiming that twenty-five percent of pilots and air crew members in the Guard and Reserve have changed their status or transferred since September 1998, with twentyfive percent of those departing citing the anthrax vaccine as the major basis for their decision) (on file with the Duke Law Journal).
} 


\section{THE ANTHRAX THREAT}

A tiny amount can kill a lot of people, and quickly. One cubic centimeter of anthrax bacteria-less than a thimbleful-dispersed into the air could potentially kill hundreds of people. ${ }^{23}$

There is no question that anthrax is a deadly biological weapon with the potential to cause significant destruction and loss of life. ${ }^{24}$ Inhalation of anthrax spores poses particularly great danger because the spores can be stored for decades and spread over large areas. ${ }^{25}$ The Department of Defense (DOD) believes that "anthrax can make an excellent weapon of mass destruction. The spores may be used as a weapon in a variety of delivery systems. ${ }^{26}$ The Mayo Clinic, in a study of anthrax's potential use as a biological weapon, concluded that "if billions of anthrax spores were in the air-as could be the case if anthrax were disseminated by the explosion of a missile-you would only have to take one or two deep breaths to inhale enough organisms to cause serious infection. ${ }^{27}$

Unclassified intelligence information reports that at least ten nations are developing an offensive capacity to use anthrax in biological warfare: China, Iran, Iraq, Israel, Libya, North Korea, South Korea, Syria, Taiwan, and Russia. ${ }^{28}$ Egypt, Cuba, Japan, and the former Soviet Republics also are on some unclassified lists. ${ }^{29}$ The DOD considers many areas where U.S. troops are stationed "high-threat" areas for anthrax attacks, including Korea, Bahrain, Jordan, Kuwait, Oman, Saudi Arabia, Qatar, United Arab Emirates, Yemen and Israel. ${ }^{30}$

The anthrax threat is compounded by the fact that there is no immediate outward indication that an individual has been exposed to anthrax - there is no cloud particle or distinct color, no smell, and no

23. Dr. Frank Cockerill, Anthrax-Ancient Disease Turned Biological Weapon, Mayo Clinic, at http://www.mayohealth.org/mayo/9802/htm/anthrax.htm (last visited Oct. 9, 2000) (on file with the Duke Law Journal).

24. HOUSE REPORT, supra note 8, at 19 ("Anthrax is the primary biological warfare threat faced by U.S. forces.”); U.S. Dep’t of Def., Anthrax: Questions and Answers, supra note 10 ("[t]he Chairman of the Joint Chiefs of Staff named anthrax as the \#1 biological threat").

25. U.S. Dep't of Def., Anthrax: Questions and Answers, supra note 10.

26. U.S. Dep't of Def., Anthrax: The Disease, at http://www.anthrax.osd.mil/Site_Files/qna/ DISEASE.htm (last visited Apr. 2, 2001) (on file with the Duke Law Journal).

27. Cockerill, supra note 23.

28. HOUSE REPORT, supra note 8, at 18 .

29. Id.

30. Id. 
taste. ${ }^{31}$ Nor is there an effective treatment for unvaccinated victims of anthrax. However, if discovered early enough after infection (usually within twenty-four to forty-eight hours), a high dose of antibiotics can reduce the death rate of unvaccinated victims from $99 \%$ to $80 \% .{ }^{32}$ To vaccine proponents, this paltry success rate reinforces the need for troops to be vaccinated against anthrax. The DOD believes the anthrax vaccination program is necessary because vaccination is the most effective way to provide protection against anthrax. ${ }^{33}$

Opponents of mandatory vaccination argue that the DOD overstates the anthrax threat and the department's response is "wellintentioned" but "over-broad." "The House Government Reform Committee asserts that AVIP was "[b]orn of a post-Gulf War panic over apparent weaknesses in chemical and biological warfare defenses, [and] the AVIP is an unmanageably broad military undertaking built on a dangerously narrow scientific and medical foundation." 35 Over the past one hundred years, only one person has died in a chemical or biological terrorist attack on United States soil. ${ }^{36} \mathrm{Dr}$. Jonathan Tucker, a former United Nations weapons inspector in Iraq, agrees that the threat is exaggerated:

U.S. policy-makers ... have predicted catastrophic consequences if a terrorist group ... mounts a major chemical or biological attack. ... But these scenarios have not drawn on a careful assessment of terrorist motivations and patterns of behavior .... [A]ctual attacks were few in number, small in scale, and generally produced fewer casualties than conventional bombs. ${ }^{37}$

Vaccination opponents assert that the only places where the existence of anthrax-spore stock has been confirmed are Southwest Asia,

31. U.S. Dep't of Def., supra note 26.

32. $I d$.

33. Id.

34. HOUSE REPORT, supra note 8 , at 17 .

35. Id. at 2 .

36. CBS News, A Realistic View of Terrorism?, at http://cbsnews.com/now/story/ 0,1597,158295-412,00.shtml (last visited Dec. 10, 2000) (on file with the Duke Law Journal). The victim was Marcus Foster, a school superintendent. Id. He was shot by the Symbionese Liberation Army in 1973, and "[h]is case counts only because the bullet was tipped with cyanide. The fact of the matter is that making a weapon of mass destruction from scratch is extraordinarily difficult." Id.

37. Jonathan B. Tucker \& Amy Sands, An Unlikely Threat, BULl. OF ATOMIC SCIENTISTS, July/Aug. 1999, at 46, 46-47. 
Northwest Asia, and Iraq. ${ }^{38}$ Thus, the House Government Reform Committee concluded that the anthrax threat was "tactically limited and regional," but the DOD's solution was "universal.," ${ }^{39}$ In the final analysis, it is difficult for civilians to assess the threat because most information involving biological warfare capabilities and intentions of other countries is classified for national security purposes. ${ }^{40}$

\section{The ANTHRAX VACCINE-ThE MEDICAL CONTROVERSY}

At best, the vaccine provides some measure of protection to most who receive it. Just how much protection is acquired, by whom, for how long, and against what level of challenge are questions DOD answers with an excess of faith but a paucity of science. ${ }^{41}$

This part explores the concerns of medical and service personnel about the health risks associated with anthrax vaccination, its longterm effects, and its efficacy. Some service members have concluded the vaccine is both unsafe and unnecessary. ${ }^{42}$ The medical controversy over the vaccine has, in large part, engendered a political controversy. The confusion regarding the vaccine has been exacerbated by House Government Reform Committee hearings, which ultimately resulted in a formal recommendation that the DOD halt the anthrax vaccination program. ${ }^{43}$

The vaccine originally was recognized by the U.S. Food \& Drug Administration (FDA) as "Anthrax Vaccine Absorbed" (AVA) and was first developed for use in human beings in the 1950s. ${ }^{44}$ AVA involves six shots over an eighteen-month immunization schedule. ${ }^{45}$ The vaccine, according to the DOD, has been used in the past by professionals who are susceptible to contracting anthrax through the skin,

38. House REPORT, supra note 8, at 19-20.

39. Id. at 20. Iraq has admitted to loading anthrax spores into warheads during the Gulf War. U.S. Dep't of Def., Anthrax: Questions and Answers, supra note 10.

40. HOUSE REPORT, supra note 8, at 23.

41. Id. at 2

42. See, e.g., Funk, supra note 15 (detailing the case of Dr. John Buck, an Air Force physician who refused the vaccine); Vela, supra note 2 (discussing Major Sonnie Bates's refusal to accept the vaccine).

43. HOUSE REPORT, supra note 8 , at 4.

44. U.S. Dep't of Def., Anthrax Vaccine-Overview, at http://www.anthrax.osd.mil/ Site_Files/qna/OVERVIEW.htm (last visited Oct. 9, 2000) (on file with the Duke Law Journal).

45. Id. The schedule for anthrax vaccinations is day 1,2 weeks, 4 weeks, 6 months, 12 months, and 18 months. Id. 
such as veterinarians, laboratory workers, and livestock handlers. ${ }^{46}$ The 1970 AVA vaccine is FDA-licensed and approved. ${ }^{47}$ Those who argue that an order to take the vaccine is illegal contend that FDA approval is illusory and that the vaccine should be considered an investigational new drug (IND) under FDA guidelines. ${ }^{48}$ Under federal law, drugs classified as INDs cannot be administered without the informed consent of the patient. ${ }^{49}$ If the use, dosage, or formula of a previously approved vaccine is altered, under FDA guidelines, the vaccine is considered an investigational new drug. ${ }^{50}$ These legal issues are discussed in more detail in Part III.

Multiple studies have tested the effectiveness of the anthrax vaccine. However, these studies have been conducted only on animals, and there have been no studies of the vaccine's efficacy on humans who are exposed to anthrax through inhalation. ${ }^{51}$ Various medical

46. U.S. Dep't of Def., Anthrax Vaccine-The Vaccine, at http://www.anthrax.osd. mil/Site_Files/vaccine/vaccine_info.htm (last visited Oct. 9, 2000) (on file with the Duke Law Journal).

47. Id. There are four stages to the FDA vaccine approval process: a pre-clinical stage, an investigational new drug stage, a product license application process, and last, a post-licensure stage. Lt. Col. John J. Michels, Jr. \& Major Bruce Smith, Legality of Orders to Submit to Anthrax Vaccination pt. III.B.1., available at http://www.majorbates.com/law/thebrief_html.htm (last visited Nov. 10, 2000) (on file with the Duke Law Journal). See generally Investigational New Drug Application, 21 C.F.R. $§ 312$ (2000) (describing the procedures and requirements governing the use of investigational new drugs). A drug must complete all the stages to be FDA-licensed and approved. Michels \& Smith, supra, pt. III.B.1.

48. Michels \& Smith, supra note 47, pt. III.B.

49. See 10 U.S.C. $\$ 1107$ (a) (Supp. V 1999) (requiring informed consent when investigational new drugs are required for members of the armed forces); 21 U.S.C. § 355(i)(4) (Supp. V 1999) (mandating informed consent for human users of investigational new drugs used for research by experts); Exec. Order No. 13,139, 3 C.F.R. § 221 (2000) (ordering that informed consent be obtained from each individual in the armed forces using an investigational new drug unless waiver can be justified to the President), reprinted in 10 U.S.C. § 1107 (Supp. V 1999). Informed consent is defined as "[a] patient's knowing choice about treatment or a procedure, made after a physician or other healthcare provider discloses whatever information a reasonably prudent provider in the medical community would provide to a patient regarding the risks involved in the proposed treatment." BLACK's LAW DICTIONARY 300 (7th ed. 1999).

50. Jay M. Zitter, Annotation, What Is a "New Drug" Within Meaning of $\$ 201(p)$ of the Federal Food, Drug, and Cosmetic Act, 133 A.L.R. Fed. 229, § 2[a] (1996); Michels \& Smith, supra note 47, pt. III.B.1; see also United States v. Articles of Drug Consisting of the Following: 5906 Boxes, 745 F.2d 105, 115-19 (1st Cir. 1984) (holding that drugs that are not adequately tested are considered investigational regardless of usage); Hoffman v. Sterling Drug, 485 F.2d 132,137-39 (3d Cir. 1973) (stating that a drug originally used to treat malaria is to be considered a "new" IND drug for the purposes of treating lupus).

51. See House Report, supra note 8 , at 42 (describing a GAO Report finding that the only studies conducted on humans were those performed by Brachman, which used the original vaccine that was not meant to prevent inhalation anthrax). 
studies conducted on guinea pigs and nonhuman mammals concluded that the vaccine protects animals exposed to anthrax through skin contact. $^{52}$ Dr. Meryl Nass, an anthrax vaccine expert, summarized these studies when testifying before Congress: "One can see varying survival rates from $0-100 \%$ depending upon the strain of anthrax used and possibly other parameters of the experiments., ${ }^{53}$ Dr. J. Jarrett Clinton, the former deputy assistant secretary of defense for health operations policy, has disagreed with Dr. Nass and claimed that studies show that the survival rate for vaccinated nonhuman mammals is $95 \%{ }^{54}$

Another concern is that no animal-human correlation studies prove that vaccinated human beings are protected from anthrax. The U.S. Government Accounting Office (GAO) reports that "several studies have shown no direct comparison of immunity in humans to that in monkeys." ${ }^{55}$ The producer of the anthrax vaccine also noted that "to date, no animal or other potency test has been demonstrated to be well correlated with protection of humans. The potency test required for the present vaccine has not been well correlated to efficacy in humans and it is doubtful it can be." ${ }^{, 56}$ Moreover, the current vaccine may not protect against genetically engineered and altered anthrax strains. This claim has been bolstered by recent, unconfirmed

52. U.S. Gov'T ACCOUNTING OfFICE, Medical REAdiness: DoD FaCES Challenges IN IMPLEMENTING ITS ANTHRAX VACCINE IMMUNiZATION PROGRAM 56 (1999).

53. Prepared Statement of Dr. Meryl Nass, Comm. on Gov't Reform, Subcomm. on National Security, Veterans Affairs, and International Relations [NSVAIR] Anthrax Hearing (II) 108 , quoted in HOUSE REPORT, supra note 8, at 59. Dr. Nass also told the Committee that survival rates in guinea pigs varied from $23 \%$ to $71 \%$ when they were exposed to inhalation anthrax. Id.

54. Dr. J. Jarrett Clinton, Anthrax Vaccine Presentation (2000) (videotaped presentation on file with the Duke Center on Law, Ethics and National Security). This presentation is based on a study of rhesus monkeys that concluded that the monkeys had a $95 \%$ survival rate. Id. (citing Prepared Statement of Dr. Sue Bailey, Asst. Secretary for Health Affairs, Dep't of Def., NSVAIR Anthrax Hearing (I), at 11); see U.S. Dep't of Def., Anthrax Vaccine: Effectiveness § 5, at http://www.anthrax.osd.mil/Site_Files/qna/EFFECTIVENESS.htm (last visited Apr. 9, 2001) (reporting an experiment in which forty-four of forty-five vaccinated monkeys exposed to inhaled anthrax survived with full health) (on file with the Duke Law Journal).

55. U.S. Gov'T ACCOUNTING OFFICE, supra note 52, at 56.

56. Mich. Biologic Prods. Inst., Investigational New Drug Application for Anthrax Vaccine Absorbed 28-29 (Sept. 20, 1996) (unpublished manuscript on file with the Duke Law Journal); see also HOUSE REPORT, supra note 8 , at 60 (citing a study suggesting that the DOD is incapable of "performing accurate monitoring because of the DOD's 'institutionalized resistance to associating health effects with the vaccine"”). 
reports that Russian government scientists have genetically altered strains of anthrax to create a new biological weapon. ${ }^{57}$

Long-term studies of the vaccine's effect on humans have not been conducted. ${ }^{58}$ Studies of the vaccine's effect on animal carcinogenesis or the impairment of fertility have not been conducted. ${ }^{59}$ The vaccine was approved in 1970 only for cutaneous (skin) exposure to anthrax, not exposure through inhalation. ${ }^{60}$ It is unlikely, according to Congress, that the vaccine would be approved under today's regulatory scheme because of the increased scrutiny and scientific standards the FDA employs. ${ }^{61}$ Both the GAO and Committee on Government Reform have concluded the vaccine is not safe and effective: "concerns about the efficacy, and by implication the necessity, of the vaccine are legitimate given the extent of unproven, unknown, and perhaps unknowable, aspects of the protection afforded., ${ }^{, 2}$

The DOD counters that the vaccine is safe and points to a plethora of published reports and studies to bolster its claim. The Centers for Disease Control also have concluded the anthrax vaccine is safe. ${ }^{63}$ A study published in the Journal of the American Medical Association determined that the potential benefits of the vaccine outweigh the risks. ${ }^{64}$ The American Public Health Association concluded that "evidence indicates that this vaccine is effective in preventing cutaneous [skin] and inhalation anthrax . . . [and] it may . . . be used to protect military personnel against potential exposure to anthrax used as a biological warfare agent." ${ }^{65}$

57. William J. Broad, Gene Engineered Anthrax: Is It a Weapon?, N.Y. TIMES, Feb. 14, 1998, at A4; Former Soviet Biological Warfare Plants Still Pose Threat, Despite Transfer to Peaceful Research, Cornell Researcher Says, SCIENCEDAILY MAG., Feb. 19, 2000, at http://www. sciencedaily.com/releases/2001/02/010219081219.htm (on file with the Duke Law Journal).

58. HOUSE REPORT, supra note 8 , at 57 .

59. Id.

60. Anthrax Vaccine Adsorbed: Product Information Insert, at http://www.bioport.com/ PrincipleProducts/AVAInsert/AVA_Images/anthrax1.jpg (last modified Mar. 1999) (on file with the Duke Law Journal).

61. HOUSE REPORT, supra note 8, at 64 .

62. Id. at 61 .

63. Food and Drug Admin., Biological products; Bacterial Vaccines and Toxoids; Implementation of Efficacy Review, 50 Fed. Reg. 51,002-117 (Dec. 13, 1985); see also U.S. Dep’t of Def., supra note 44, $\$ 10$ ("Today, there is a broad consensus that the FDA-licensed anthrax vaccine is safe and effective for people at high risk of exposure.").

64. Arthur M. Friedlander et al., Anthrax Vaccine: Evidence for Safety and Efficacy Against Inhalation Anthrax, 281 JAMA 2104, 2106 (1999).

65. See Am. Pub. Health Ass'n, Control of Communicable Diseases Manual (17th ed. 2000), quoted in U.S. Dep't of Def., Anthrax Vaccine: Safety, at http://www.anthrax. 
FDA officials also have insisted the vaccine is safe. On November 3, 1999, four members of Congress asked the FDA to reclassify the anthrax vaccine as an IND, ${ }^{6}$ thereby rendering it illegal for the DOD to administer it to service members without their informed consent. $^{67}$ The FDA responded on November 26, 1999, that "there is presently no basis for concluding that the anthrax vaccine, a licensed product, when used in accordance with current labeling, should be used pursuant to an IND application or, as requested in your letter, that FDA 'place the anthrax vaccine back under IND status." ${ }^{68}$ A 1997 letter from the FDA's Dr. Michael Friedman to DOD officials reached the same conclusion. ${ }^{69}$

To ensure the safety and effectiveness of the AVIP Program, Secretary Cohen required that AVIP meet certain safety, operational, tracking, and medical conditions before it was fully implemented. ${ }^{70}$ After a multiple-year review of the conditions, Secretary Cohen, in 1998, decided that these requirements were satisfied and stated that "all conditions for implementing the anthrax vaccination program for the total force have now been met." "One of the conditions included a review of the entire program by an independent medical expert. The former dean of the Yale Medical School, Dr. Gerald Burrow, conducted the review and concluded that the entire anthrax vaccination program-including the health and medical aspects-was safe and effective. ${ }^{72}$

osd.mil/Site_Files/safety/safety_info.htm (last visited Apr. 9, 2001) (on file with the Duke Law Journal).

66. The specifics of IND status are examined thoroughly infra Part III.B.

67. See Letter from Dan Burton et al., Representatives, U.S. House of Representatives, to Dr. Jane E. Henney, Commissioner, FDA (Nov. 3, 1999) (on file with the Duke Law Journal).

68. Letter from Melinda K. Plaisier, Associate Commissioner for Legislation, FDA, to Dan Burton et al., Representatives, U.S. House of Representatives (Nov. 26, 1999) (on file with the Duke Law Journal)

69. See Letter from Dr. Michael Friedman, Lead Deputy Commissioner, FDA, to Dr. Stephen C. Joseph, Assistant Secretary of Defense for Health Affairs, Department of Defense (Mar. 13, 1997) (on file with the Duke Law Journal).

70. The four factors designated by Secretary Cohen were: (1) supplemental testing to assure sterility, safety, potency, and purity of the vaccine stockpile; (2) implementation of a system for fully tracking anthrax immunizations; (3) approval of operational plans to administer the vaccine and communications plans to inform military personnel; and (4) review of medical aspects of the program by an independent expert. Memorandum from William S. Cohen to the Secretaries of the Military Departments, supra note 20.

71. Id.

72. U.S. Dep't of Def., supra note 65; see also Clinton, supra note 54 (discussing a study finding that rhesus monkeys exposed to the anthrax vaccine had a $95 \%$ survival rate). 
The contentious medical controversy, in turn, stirs the legal controversy and serves as a basis for the defendant who refuses the anthrax vaccine to claim that an order to take the vaccine from a superior officer is illegal.

\section{THE LEGAL CONTROVERSY}

[The military judge] also ruled that the order of the commanding officer to the petitioner, to report to the medical building and receive an anthrax vaccination, was a lawful order and that she would inform the members that the order was lawful. ${ }^{73}$

The legal controversy over AVIP involves military, political, and medical issues. The basic legal issue centers on whether a service member can be ordered to submit to anthrax vaccination. The DOD's legal approach is straightforward: the vaccine is safe, effective, and FDA-approved, and under existing case law, the determination of the order's legality is a question of law for a judge to decide, rather than a factual issue for determination by a jury.

The refusing service member's argument is more complicated: the order to take the anthrax vaccine is illegal because the vaccine is an experimental drug, and under federal law, it is illegal to use an experimental drug on non-consenting subjects. Service members can refuse to follow illegal orders. ${ }^{74}$ Thus, the argument concludes, the service member's decision not to follow the order was proper because the order was illegal. The following subparts explore both of these arguments in more detail.

73. Perry v. Wesely, No. NMCM 200001397, 2000 WL 1775249, at*1 (N-M. Ct. Crim. App. Nov. 29, 2000).

74. See U.S. Gov'T, MANUAL FOR COURTs-Martial pt. IV, II 14c(2)(a)(i) (1998) ("When an accused is charged with willful disobedience of a lawful order under Article 90, UCMJ, the order is presumed to be lawful, unless it is patently illegal."). Defenses for refusal to follow a lawful command or order are varied. The defenses include justification, necessity, duress, inability, ignorance, or mistake. Id., Rule 196, II-111-114 (2000); Statement of John J. Michels, Jr., House Comm. on Gov't Reform, at http://www.house.gov/reform/hearings/ healthcare/00.10.03/michels.htm (Oct. 3, 2000) [hereinafter Michels Statement] (on file with the Duke Law Journal). However, in regards to orders to take anthrax inoculations, "the most likely defense is that the order conflicts with a statutory right of the person receiving the order, i.e., the right to provide informed consent to the vaccination under 10 U.S.C. $§ 1107$ or Executive Order 13139." Id.; see also U.S. Gov’T, supra, pt. IV, II 14c(2)(a)(iv). Section 1107 and Executive Order 13,139 are discussed extensively infra at Part III.B. 


\section{A. The Case for the Legality of the Order}

The case for the legality of an order to take the anthrax vaccine is relatively clear: disobedience of a direct, lawful order from a superior officer is punishable under Articles 90 or 92 of the Uniform Code of Military Justice (UCMJ). Article 90 prohibits willfully disobeying a superior commissioned officer, ${ }^{75}$ Article 92 prohibits failing to obey an order or regulation. ${ }^{76}$ If the subject who refuses the vaccine is courtmartialed, the government files multiple interlocutory motions: (1) that the lawfulness of the order should be decided as a question of law and (2) that all evidence regarding the safety, efficacy, and necessity of the vaccine should be excluded. ${ }^{77}$

A military order may be presumed lawful when an accused is charged with willful disobedience of a lawful order $;^{78}$ however, this presumption is rebuttable. Moreover, the lawfulness of the order is an issue to be resolved as an interlocutory matter by a judge. ${ }^{79}$ If the military judge determines the order is lawful because lawfulness has not been rebutted, the issue is not put to the jury. ${ }^{80}$

Thus, if these dual motions are granted, the jurors do not consider the safety, necessity, and efficacy of the vaccine. ${ }^{81}$ Since there are no reported cases where the military judge has denied the government's aforementioned motions regarding the anthrax vaccine, the

75. Article 90 provides that "[a]ny person subject to this chapter who ... willfully disobeys a lawful command of his superior commissioned officer; [sic] shall be punished ... if the offense is committed at any other time [than war], by such punishment, other than death, as a courtmartial may direct.” 10 U.S.C. $\$ 890$ (1994) (U.C.M.J. Art. 90).

76. 10 U.S.C. $\$ 892$ (1994) (U.C.M.J. Art. 92):

Any person subject to this chapter who-(1) violates or fails to obey any lawful general order or regulation; (2) having knowledge of any other lawful order issued by any member of the armed forces, which it is his duty to obey, fails to obey the order ... shall be punished as a court-martial may direct.

77. See, e.g., Ponder v. Stone, 54 M.J. 613, 614 (N-M. Ct. Crim. App. 2000) (holding that the legal authority of an order is not based on the safety of the vaccine).

78. U.S. GoV'T, supra note 74, pt. IV-19, It 14c(2)(a)(i).

79. Perry v. Wesely, No. NMCM 200001397, 2000 WL 1775249, at $* 3$ (N-M. Ct. Crim. App. Nov. 29, 2000); United States v. New, 50 M.J. 729, 739 (A. Ct. Crim. App. 1999).

80. U.C.M.J. § 851, art. 51(b), reprinted in MANUAL FOR COURTS-MARTIAL A2-14 (1998); R.C.M. 801 (e)(1), (5), Discussion, reprinted in MANUAL FOR COURTS-MARTIAL II75-76 (1998). Unlike civilian jurors, military jurors, known as "members," are not chosen at random. U.C.M.J. $\S 825$, art. 25(a), (d)(2). Members are selected by the court-martial Convening Authority on the basis of their "age, education, training, experience, length of service, and judicial temperament." Id. art. 51(d)(2). The Uniform Code of Military Justice provides that, whenever possible, "no member of an armed force may be tried by a court-martial any member of which is junior to him in rank or grade." Id. art. 51(d)(1).

81. Perry, $2000 \mathrm{WL} 1775249$, at $* 3$. 
defense essentially is left without a case. Once the motions are granted, the defendant can appeal and seek a writ of mandamus ordering reversal of the twin interlocutory motions, but in the cases decided to date, this request always has been denied. ${ }^{82}$

The prosecution has historical precedent as a basis on which to argue that the order to take the vaccine is lawful. As commander of the Continental Army during the Revolutionary War, General George Washington mandated smallpox vaccinations for troops in $1777 .^{83}$ On the legal front, United States v. Chadwell ${ }^{84}$ also provides support for the legality of orders to take vaccines. In Chadwell, the Navy Board of Review (now the Navy-Marine Corps Court of Criminal Appeals) upheld the convictions of two marines who refused to submit to smallpox, typhoid, paratyphoid, and influenza vaccinations because of religious beliefs, which the seamen argued were constitutionally protected. ${ }^{85}$ The Chadwell court stated that religious beliefs were not above military orders: "to permit this would be to make the professed doctrines of religious belief superior to military orders, and in effect to permit every soldier to become a law unto himself. The military would be impotent under such circumstances." ${ }^{, 86}$ Moreover, the opinion emphasized that the service members volunteered for service and "elected to become members of the military," so they easily could have followed their religious beliefs by not joining the Marine Corps in the first place. ${ }^{87}$ Even if they had not volunteered, the Supreme Court has held that compulsory vaccinations by local health boards do not violate the Constitution. ${ }^{88}$ In the context of anthrax, court-martialed members generally refuse the vaccine because of health and safety reasons, which arguably are entitled to less con-

82. See, e.g., Ponder, 54 M.J. at 617 (rejecting a petition a for writ of mandamus); Rose v. Delzompo, No. NMCM 200001187 (N-M. Ct. Crim. App. Nov. 29, 2000) (on file with the Duke Law Journal).

83. U.S. Dep't of Def., Desk Reference on Vaccines and Immunity, at http://www.anthrax. osd.mil/Site_Files/articles/INDEXclinical/Desk_Ref_files/mvp-guide.htm (last visited Apr. 6, 2001) (on file with the Duke Law Journal).

84. 36 C.M.R. 741 (1965).

85. Id. at 748 .

86. Id.

87. $I d$.

88. See Jacobson v. Massachusetts, 197 U.S. 11, 18-19 (1905) (holding that the Massachusetts smallpox compulsory vaccination program was not an unreasonable invasion of an individual's liberty and had a real and substantial relation to the protection of the public health and safety). 
stitutional protection than religious beliefs. No explicit constitutional provision guarantees the protection of citizens' health. ${ }^{89}$

A recent Army Court of Criminal Appeals decision that bolsters the government's case is United States $v$. New. ${ }^{90}$ Specialist Michael New refused an order to wear United Nations (UN) accoutrements on his Army battle dress uniform because he believed wearing the UN insignia constituted an "involuntary change of allegiance from the United States to the United Nations." guilty of failure to obey a lawful order and sentenced to a bad conduct discharge. ${ }^{92}$ The Army Court of Criminal Appeals affirmed the sentence and made important findings regarding the legality of orders: (1) "an order is presumed to be lawful" and a "soldier disobeys an order on his own personal responsibility and at his own risk" ${ }^{\text {"93 }}$; (2) the accused charged with disobeying lawful orders "bears the heavy burden of showing that the orders were illegal""; and (3) "unless the order requires an obviously illegal act, or is obviously beyond the issuer's authority, the service member will obey the order."

Prosecutors use this case in courts-martial to stand for the proposition that as a matter of law an order to submit to anthrax vaccination is legal, just as the order to wear the UN patch was legal. ${ }^{96}$ Instructors at the Naval Justice School instruct attorneys to use New when arguing anthrax legality issues. The instructors believe New establishes the legality of the order as a matter of law. The only issues left under Article 90 are whether the military member knew of the order and whether or not he followed the order. ${ }^{97}$ The jury does not get to decide the lawfulness issue. ${ }^{98}$ The use of New in the future is uncertain, however, because the case is under review by the U.S.

89. In fact, about the time Chadwell was decided, Justice Stewart referred to freedom of religion as the most important freedom guaranteed by our Constitution: "I am convinced that no liberty is more essential to the continued vitality of the free society which our Constitution guarantees than is the religious liberty protected by the Free Exercise Clause." Sherbert v. Verner, 374 U.S. 398, 413 (1963) (Stewart, J., concurring).

90. 50 M.J. 729 (A. Ct. Crim. App. 1999).

91. Id. at 734 .

92. Id. at 733. Specialist New was found guilty of violating Article 92 of the U.C.M.J. Id.

93. Id. at 739 (citation omitted).

94. Id.

95. Id.

96. E-mail from Captain John Deaton, U.S. Navy, to Randall D. Katz (Dec. 5, 2000) (on file with the Duke Law Journal).

97. Id.

98. Id. 
Court of Appeals for the Armed Forces. ${ }^{99}$ Another advantage for the prosecution is that at least one court has commented that the question of the anthrax program's legality was a political decision made by Secretary Cohen and is therefore a nonjusticiable political question. ${ }^{100}$

Litigated cases use the aforementioned government arguments. The recent case of Marine Corps Lance Corporal Ocean Rose is typical. ${ }^{101}$ Rose was charged with willfully disobeying his superior officer's order to take his third anthrax shot, in violation of Articles 90 and 92, UCMJ. ${ }^{102}$ The military judge heard dual government motions to exclude evidence pertaining to the licensing, safety, and efficacy of the vaccine and to rule that the order was legal as a matter of law. ${ }^{103}$ The judge granted both of the government's motions. ${ }^{104}$ Lance Corporal Rose appealed to the Navy-Marine Corps Court of Criminal Appeals and requested extraordinary relief in the form of a writ of mandamus. ${ }^{105}$ The request was denied, and Lance Corporal Rose was precluded from presenting any factual evidence. ${ }^{106}$ Most, if not all, of the cases denying the mandamus petition read like Rose's case; in fact,

99. United States v. New, 52 M.J. 465, 465 (C.A.A.F. 1999) (granting review). As of the date of publication (April 2001), the U.S. Court of Appeals for the Armed Forces has yet to decide New.

100. See Perry v. Wesely, No. NMCM 200001397, 2000 WL 1775249, at *3 n.2 (N-M. Ct. Crim. App. Nov. 29, 2000) ("Complicating the inquiry in the petitioner's case is his effort to contest the lawfulness of the commanding officer's order by litigating the legality of the DoD anthrax vaccination program itself, a nonjustiticable political decision."). For a discussion involving whether an issue constitutes a political question, see Baker v. Carr, 369 U.S. 186, 208-237 (1962).

101. See generally Rose v. Delzompo, No. NMCM 200001187 (N-M. Ct. Crim. App. Nov. 29, 2000) (on file with the Duke Law Journal) (detailing the case against Lance Corporal Rose for refusing to follow an order to be vaccinated).

102. Id.

103. Id.

104. Id.

105. Id.

106. Id. 
there seems to be a "cutting-and-pasting" of the same language from one anthrax appeal case to another. ${ }^{107}$

107. Compare Ponder v. Stone, 54 M.J. 613 (N-M. Ct. Crim. App. 2000), with Perry v. Wesely, No. NMCM 200001397, 2000 WL 1775249 (N-M. Ct. Crim. App. Nov. 29, 2000).

In Ponder, Navy-Marine Corps Court of Criminal Appeals Senior Judge Leo, joined by Judges Anderson and Naugle wrote:

After receiving evidence and hearing argument from counsel, the military judge in this case ruled that the petitioner's order was lawful as a matter of law and stated that he would so instruct the court-martial members, thereby precluding the petitioner from putting the matter before the members as an issue of fact.

The petitioner had argued that, by statute, informed consent must be obtained by the Secretary of Defense from members of the Armed Forces before an IND or a drug unapproved for its applied use may be administered, unless the President waives this requirement. 10 U.S.C. $§ 1107(f)(1)$. Similarly, he argued that informed consent must be obtained by the Secretary of Defense from any human subject of an experiment or a test directly related to protection against toxic chemicals or biological weapons and agents. 50 U.S.C. $\S 1520 \mathrm{a}(\mathrm{c})$. Therefore, he wanted to introduce evidence showing that the anthrax vaccine was the type of drug requiring informed consent under both statutes.

Executive Order 13139, which implements 10 U.S.C. § 1107, clearly states that the requirements it incorporated from the statute are for internal management only and confer no right enforceable by any party against the United States. E.O. 13139, § 6(b). Additionally, Secretary of the Navy Instruction 6230.4 of 29 April 1998, which implements the Department's anthrax vaccination implementation program [DON AVIP], states that the anthrax vaccine is a FDA-licensed product and not an IND requiring informed consent for its administration. ... This would imply that the vaccine is also not an experimental or test drug that would require informed consent under 50 U.S.C. $\$ 1520 \mathrm{a}(\mathrm{c})$. According to the DON AVIP instruction, anthrax immunization is mandatory and those refusing the vaccine are subject to disciplinary action. SECNAVINST 6230.4, Annex E to Enclosure (1) at E-11. Under these circumstances, the petitioner has not shown that the military judge's ruling is so contrary to statute, settled case law, or valid military regulation as to deny him relief that is clearly and indisputably due him as a matter of right. [McKinney v. Jarvis, 46 M.J. 870, 874 (A. Ct. Crim. App. 1997)]. Accordingly, we find that the issuance of an extraordinary writ at this time is neither necessary nor appropriate.

Ponder, 54 M.J. at 616-17.

In Perry, Navy-Marine Corps Court of Criminal Appeals Judges Dorman, Ozmun, and

Naugle, in a per curium opinion, wrote:

After receiving evidence and hearing argument from counsel, the military judge in this case ruled that the petitioner's order was lawful as a matter of law and stated that she would so instruct the court-martial members, thereby precluding the petitioner from putting the matter before the members as an issue of fact. The petitioner argued on the motion that, by statute, informed consent must be obtained by the Secretary of Defense from members of the Armed Forces before an IND or a drug unapproved for its applied use may be administered, unless the President waives this requirement. 10 U.S.C. $\$ 1107$ (f)(1). Similarly, Executive Order 13139 also requires informed consent. Therefore, the petitioner sought to introduce evidence showing that the anthrax vaccine was the type of drug requiring informed consent under both the statute and the Executive Order. Executive Order 13139, which implements 10 U.S.C. § 1107, however, clearly states that the requirements that it incorporated from that statute are for internal management only and confer no right enforceable by any party against the United States. E.O. 13139, § 6(b). Additionally, Secretary of the Navy Instruction 6230.4 of 29 April 1998, which implements the Department's anthrax vaccination implementation program [DON AVIP], states that the anthrax vaccine is an FDA-licensed product and not an IND requiring informed consent for its administration... That would imply that the vaccine is also not an experimental or test drug 
The case of Builder Third Class David Ponder reads similarly. ${ }^{108}$ The military judge granted the dual government motions ${ }^{109}$ and this determination was upheld on appeal. ${ }^{110}$ In fact, the government's position always has been upheld on appeal. No defendant, in any branch of the Armed Forces, has been able to argue successfully the merits (including the safety, efficacy, and necessity) of the anthrax vaccine. The government's strategy, which has been wholly successful, is to foreclose the case procedurally before the merits can be substantively evaluated. The defense is left defenseless.

\section{B. The Case Against the Legality of the Order}

A soldier prosecuted for refusing to submit to anthrax vaccination would make a complex argument, if permitted to defend himself on the substantive merits. The defense would involve a three-step argument. First, the anthrax vaccine is not FDA-approved because of alterations in its chemical formula and a change in its intended use from the original vaccine. As such, the FDA must consider it an IND. Second, since the vaccine is an IND, it requires informed consent of the service member under federal law and a Presidential Executive Order. Third, since the current vaccine is illegal to administer and was administered without consent, the order directing the service member to become vaccinated was illegal.

The defense would argue that the anthrax vaccine should be characterized as an IND under FDA regulations because the vaccine is improperly used and because the purpose for which it is now used

\footnotetext{
that would require informed consent. According to this instruction, anthrax immunization is mandatory and those refusing the vaccine are subject to disciplinary action. . .

Under these circumstances, the petitioner has not shown that the military judge's rulings are so contrary to statute, settled case law, or valid regulation as to deny him relief that is clearly and indisputably due him as a matter of right. [McKinney v. Jarvis, 46 M.J. 870, 874 (A. Ct. Crim. App. 1997)]. Accordingly, we find that the issuance of an extraordinary writ at this time is neither necessary nor appropriate.
}

Perry, 2000 WL 1775249, at*3-4. Perry appealed his case to the U.S. Supreme Court, but his petition for writ of mandamus was denied. In re Perry, 121 S. Ct. 1396 (2001). His claim that the military judge violated his Fifth and Sixth Amendment rights was turned down without comment. Marine Loses Appeal over Anthrax Vaccine, WASH. Post, Mar. 20, 2001, at A17; Marine Loses Challenge to Vaccine Prosecution, CNN.com (Mar. 19, 2001), at http://www.cnn.com/2001/ LAW/03/19/scotus.anthraxvaccine.ap/index.html (on file with the Duke Law Journal).

108. Ponder, 54 M.J. at 614-15.

109. Id.

110. Id. at 617 . 
differs from the purpose for which it was approved originally. ${ }^{111}$ The FDA considers a drug on IND status, even if it has been used for years, if there has been a change in the product's end use, formula, dilution, product repackaging, or route of administration. ${ }^{112}$

The 1970 anthrax vaccine (AVA) ${ }^{113}$ was approved originally for anthrax exposure through the skin, not for exposure by inhalation. The 1970 AVA was licensed for animal handlers who might come into contact with cutaneous anthrax by working with animals. ${ }^{14}$ By contrast, the main goal of the DOD's vaccination program is to prevent inhalation anthrax. If able to surmount the government's preliminary objections, ${ }^{115}$ the defense would contend that this constitutes a change in the target use of the product. The DOD and the sole AVA producer have recognized that AVA was not approved for inhalation anthrax, and they took steps in 1995 to file a new IND application to approve the vaccine for inhalation anthrax and to change the inoculation schedule from six to three doses. ${ }^{116}$ Due to production problems with the vaccine's manufacturer that have led to a shortage of the vaccine ${ }^{117}$ the DOD recently announced that soldiers who received only two shots of the six-shot sequence, but did not finish the sequence, will not have to repeat the initial sequence of shots and will be able to receive additional shots to complete the sequence for up to two years. ${ }^{118}$ Both the IND application and the DOD's differing in-

111. FDA approval is not a prerequisite for use by the DOD. The FDA only regulates the manufacturer in the vaccines' making, not use. The FDA does not have jurisdiction to regulate the administration of the AVA. See Michels \& Smith, supra note 47, pt. III.B.2.

112. See Zitter, supra note 50, at 286-91 (providing an annotation of cases illustrating a large variety of products considered "new drugs" by the FDA); Michels \& Smith, supra note 47, pt. III.B.1 (discussing IND status); see also U.S. v. Articles of Drug Consisting of the Following: 5906 Boxes, 745 F.2d 105, 113-17 (1st Cir. 1984) (holding that drugs that are not adequately tested are considered investigational regardless of usage); Hoffman v. Sterling Drug, 485 F.2d 132, 137-38 (3d Cir. 1973) (stating that drug originally used to treat malaria is to be considered a "new" IND drug for the purposes of treating lupus).

113. See supra Part II (discussing the medical aspects of the anthrax vaccine).

114. U.S. Dep't of Def., supra note 46.

115. See supra notes 78-82 and accompanying text (describing preliminary issues).

116. Michels \& Smith, supra note 47, pt. III.B.2; Sci. Applied Info. Corp., Anthrax Vaccine License Amendment Project Plan' Information Briefing for Joint Program Managers at Dep't of Def., Bio. Def. Div. (Oct. 20, 1995).

117. Infra notes $171,182$.

118. See James G. Bishop, DoD Slows down Anthrax Effort, AIR RESERVE PERSONNEL UpDATE, Sept./Oct. 2000, at 1 (interviewing Dr. Sue Bailey, Assistant Secretary of Defense for Health Affairs); Michels Statement, supra note 74; Col. Randy Randolph, Slowdown Notice, Department of Defense Anthrax Vaccine Immunization Program, at http://www.anthrax.osd. mil/HTML_interface/map/slowdownnotice.htm (last visited Apr. 26, 2001) (on file with the 
oculation schedule constitute a change in the dosage of the vaccine. Moreover, the GAO discovered that the vaccine given to service members does not have the same chemical formula as that approved by the FDA in $1970 .{ }^{119}$ This is an alteration in the drug's formula. This surprising conclusion was released in a 1999 GAO report that stated the current anthrax vaccine is not the same vaccine that was tested originally and approved prior to $1970 .{ }^{120}$ These material changes constitute changes in the target use of the product, dosage, and formula. In essence, the DOD recognized that the vaccine "as labeled, was not legally viable and undertook the appropriate steps to change product use labeling, method of administration, and vaccination schedule. These substantial changes in how this drug was to be used rendered it an IND." ${ }^{121}$ The IND application, filed in 1996, is still current and pending. ${ }^{122}$ The House Government Reform Committee agrees that AVA is an IND and contends that AVA used for inhalation anthrax is "an off-label use of the product to treat an indication for which it is not explicitly licensed. . . . Both the new indication and the new schedule should be undertaken only pursuant to FDA regulations governing clinical trials on investigational new drugs." 123

Furthermore, soldiers prosecuted for disobeying an order to submit to vaccination would argue that there have been no credible studies to demonstrate that AVA, or the current vaccine chemical mix, is effective against inhalation anthrax in humans. ${ }^{124}$ According to the First Circuit Court of Appeals, a drug must be considered an IND if there is no general evidence that a vaccine is considered effective and safe. ${ }^{125}$

Duke Law Journal). The dosage schedule for the anthrax vaccine is day 1, 2 weeks, 4 weeks, 6 months, 12 months, and 18 months. Supra note 45.

119. Medical Readiness: Safety and Efficacy of the Anthrax Vaccine: Hearing Before the House Subcomm. on National Security, Veterans Affairs, and International Relations of the House Comm. on Governmental Reform, 106th Cong. 14 (1999) (statement of Kwai-Cheung Chan) [hereinafter Chan]; see also Michels \& Smith, supra note 47, pt. III.B.2 (discussing changes in labeling, method of administration, and the vaccination schedule).

120. Chan, supra note 119.

121. Michels \& Smith, supra note 47, pt. III.B.2.

122. Id.

123. House RePORT, supra note 8, at 3; Michels \& Smith, supra note 47, pt. III.B.2.

124. See House RePORT, supra note 8, at 58 (describing a GAO Report that the only studies conducted on humans were those performed by Brachman and used the original vaccine which was not meant to prevent inhalation anthrax).

125. See United States v. Articles of Drug Consisting of the Following: 5906 Boxes, 745 F.2d 105, 117 (1st Cir. 1984) (requiring general recognition of a drug's safety and effectiveness for it to be exempt from FDA approval). 
By establishing that the vaccine is an IND, the defendant would trigger the informed consent requirement under the Notice of Use of an Investigational New Drug statute ${ }^{126}$ and Executive Order 13,139. ${ }^{127}$ The Notice of Use of an Investigational New Drug statute, 10 U.S.C. $\S 1107$, requires the Secretary of Defense to provide notice when a member of the armed forces receives "an investigational new drug or a drug unapproved for its applied use." ${ }^{128}$ Under $\S 1107(f)$, only the President of the United States has the authority and power to waive the consent requirement. ${ }^{12}$

Former President Clinton issued Executive Order 13,139, which provides in $\S 3(\mathrm{a})$ that the DOD must obtain "informed consent from each individual" to whom an IND is administered. ${ }^{130}$ Moreover, the order sharply limits presidential waivers and states that "waivers of informed consent will be granted only when absolutely necessary." The order also mandates that an IND must be grounded in scientific study: "[the IND] shall be studied through scientifically based research and development protocols to determine whether it is safe and effective for its intended use." ${ }^{132}$ The defense would argue that $\S 1107$ and Executive Order 13,139 clearly establish that the DOD must obtain informed consent unless it is waived by the President. President Clinton did not waive consent during his term of office, and President George W. Bush has yet to waive the consent requirement. ${ }^{13}$

Thus, the defense would argue that federal law requires informed consent procedures to be followed when administering an IND. Since

\footnotetext{
126. 10 U.S.C. $\$ 1107$ (Supp. V 1999).

127. Exec. Order No. 13,139, 3 C.F.R. § 221 (2000), reprinted in 10 U.S.C. $§ 1107$ (Supp. V 1999).

128. 10 U.S.C. $\$ 1107$ (a) (Supp. V 1999).

129. Id. § 1107(f).

130. Exec. Order No. 13,139, 3 C.F.R. § 221 (2000), reprinted in 10 U.S.C. $\S 1107$ (Supp. V 1999).

131. Id.

132. Id.

133. In fact, President George W. Bush expressed concern about AVIP while running for the presidency:

The Defense Department's Anthrax Immunization Program has raised numerous health concerns and caused fear among the individuals whose lives it touches. I don't feel the current administration's anthrax immunization program has taken into account the effect of this program on the soldiers in our military and their families. Under my administration, soldiers and their families will be taken into consideration.
}

The Presidential Candidates Weigh in on Federal Medicine: George W. Bush, U.S. Medicine, (Sept. 2000), at http://www.usmedicine.com/article.cfm?articleID=65\&issueID=16 (on file with the Duke Law Journal). 
the current vaccine is an IND and is illegal to administer absent informed consent or waiver, an order requiring service members to obtain the anthrax vaccination is illegal because mandatory procedures were not followed. In a recent opinion, the Navy-Marine Corps Court of Criminal Appeals, while upholding the military judge's decision to declare the order legal as a matter of law and to exclude evidence pertaining to the safety and efficacy of the vaccine, dismissed in three sentences the defense arguments based on the Notice of Use of an Investigational New Drug Statute, § 1107, and Executive Order $13,139 .{ }^{134}$ The judges stated that the Executive Order implements 10 U.S.C. $\S 1107$, and they determined that $\S 6(\mathrm{~b})$ of the Order limits the Order's scope to "internal management only and confers no rights enforceable by any party against the United States." ${ }^{135}$ Thus, the Executive Order does not confer standing on any private party.

Other than the aforementioned three-sentence determination, there is no case law evaluating the defense's possible arguments, because the defense is not allowed to make an argument on the merits.

\section{ANALYSIS}

The AVIP raises an ominous question: who protects the force from ill-conceived force protection? ${ }^{136}$

The crux of the debate concerns procedural rules (government case) versus evaluation of substantive merits (defense case). The defendant's case should be heard on the merits, and military judges should rule that the presumed lawfulness of an order to take the vaccine is rebutted by the substantial evidence regarding the IND status of the vaccine. The court should examine the evidence and then rule on the merits. However, the analysis is not that simple: as emphasized throughout this Note, the anthrax inoculation issue is an interdisciplinary one, and any analysis needs to take into account not only legal issues, but also political, medical, and human rights concerns.

There are many reasons why military courts do not fully explore the merits of anthrax vaccination refusal cases. Part IV.A. argues that military judges may be reluctant to overturn a decision made by the Secretary of Defense or high-ranking officials. This subpart also dis-

134. Perry v. Wesely, No. NMCM 200001397, 2000 WL 1775249, at *3 (N-M. Ct. Crim. App. Nov. 29, 2000).

135. Id.

136. HOUSE REPORT, supra note 8, at 3. 
cusses problems the Pentagon may face if a court does indeed decide-or the Pentagon concedes - the vaccine is an IND. The argument then shifts, in Part IV.B., to the contention that the Pentagon has admitted tacitly that the current anthrax vaccine is an IND. Part IV.C then critiques judicial arguments against hearing anthrax vaccine refusal cases. Finally, the Conclusion argues that the Pentagon must regain the trust of its service members by halting the AVIP, as recommended by a subcommittee of the House of Representatives.

\section{A. Pandora's Box and Military Judges: Caught Between the Checks and Balances}

Military judges may be reluctant to decide that an order to submit to vaccination is unlawful. Military judges are appointed to their positions by their respective Judge Advocates General and do not have Article III lifetime appointments. ${ }^{137}$ They are not as independent as Article III judges ${ }^{138}$ and may fear reprisals. Allowing the presumption of lawfulness to be rebutted would surely open a Pandora's box of sorts. One decision by one military judge in one branch of the service could be the beginning of the end for AVIP; a promising career could come to a screeching halt for the military judge who interferes with a decision made by the Secretary of Defense and highranking Pentagon Officials.

The Supreme Court recognized potential problems with the independence of military judges in Weiss $v$. United States. ${ }^{139}$ The Court noted that military judges may be reassigned at any time because they have no fixed term of office. "Commissioned Officers are assigned or detailed to the position of military judge by a Judge Advocate General for a period of time he deems necessary or appropriate, and then they may be reassigned to perform other duties." 140 Military judges also are accountable to their respective Judge Advocates General for their decisions. "By placing judges under the control of Judge Advocates General, who have no interest in the outcome of a particular

137. Military judges are appointed under the Appointments Clause of Article II. See U.S. CONST. art. II, § 2; Weiss v. United States, 510 U.S. 163, 176 (1994) (upholding the current system of appointing military judges as a constitutional application of the Appointments Clause).

138. Weiss, 510 U.S. at 175-76.

139. 510 U.S. 163 (1994). Note that the Court ruled against the petitioner's argument. The petitioner argued that military judges are not independent, neutral decisionmakers because they are not appointed to a life tenure, as are Article III judges, and that due process was denied as a result. Id. at 181.

140. Id. at 176. 
court-martial, we believe Congress has achieved an acceptable balance between independence and accountability." 141 What the Supreme Court failed to recognize is that Judge Advocates General may indeed have a significant interest in the outcome of cases when a large issue or principle is at stake. This is exactly the case with anthrax vaccinations; a ruling by a solitary military judge could halt AVIP. Judge Advocates General, who oversee military judges, would likely have an interest in that.

If AVIP were cancelled, the DOD also would face a significant problem with service members who already received the vaccination: how would the DOD defend its decision to vaccinate them? Would deciding the order was "illegal" mean the DOD treated its soldiers like guinea pigs? Such a decision could bring about an administrative nightmare of allegations, claims, and distrust. In essence, a decision to examine the merits of the case could cause a public relations maelstrom and have serious implications. However, if the vaccine is truly harmful, unsafe, and ineffective, the implications could be far more sweeping.

The Pandora's box, however, may be open already. The House Government Reform Committee held public hearings and concluded that AVIP should be suspended. ${ }^{142}$ Documents widely available on the Committee's website conflict sharply with the Pentagon's conclusions. ${ }^{143}$ This makes the decision for service members incredibly difficult; one branch of government is assuring them the vaccine is safe and effective, while a subcommittee of another branch of government is expressing grave concern about the vaccine-enough concern, in fact, to recommend the program be stopped altogether. The legality

141. Id. at 180 (emphasis added).

142. The Department of Defense Anthrax Vaccine Immunization Program: Unproven Force Protection, U.S. House of Representatives Comm. on Government Reform, Subcomm. on National Security, Veterans Affairs, and International Relations, at http://www.house.gov/reform/ ns/reports/anthrax1.pdf (Feb. 17, 2000) (on file with the Duke Law Journal). The conclusions were:

(1) force-wide, mandatory AVIP should be suspended until DOD obtains approval for an improved vaccine. To accomplish this: (2) DOD should accelerate research and testing on a second-generation, recombinant anthrax vaccine; and, (3) DOD should pursue testing of the safety and efficacy of a shorter inoculation regimen; and, (4) DOD should enroll all anthrax vaccine recipients in a comprehensive clinical evaluation and treatment program for long term study; (5) While an improved vaccine is being developed, use of the current anthrax vaccine for force protection against biological warfare should be considered experimental and undertaken only pursuant to FDA regulations governing investigational testing for a new indication.

Id.

143. Id. 
of the order is thus caught between the checks and balances of the executive and legislative branches. ${ }^{144}$

\section{B. Department of Defense Recognition of $A V A$ As an IND}

With these concerns in mind, the DOD has recognized-and tacitly admitted-that the current anthrax vaccine is an IND. The Army discussed a plan in 1995 to file an IND application to change the license of AVA to include effectiveness against inhalation anthrax and the dosage schedule..$^{145}$ In fact, the Army had Science Applied Information Corporation (SAIC), a defense contractor, prepare an "Anthrax Vaccine License Amendment Project Plan" that was presented to the Joint Program Manager for DOD Biological Defense on October 19, 1995. ${ }^{146}$ According to the briefing materials, an amendment would be sought to use the vaccine for inhalation anthrax and to reduce the number of inoculations required. ${ }^{147}$ The DOD's request that SAIC prepare a briefing in order to amend the AVA license strongly suggests that the DOD recognizes that the vaccine is an IND.$^{148}$ Moreover, in 1996, Bioport, the sole producer of AVA, filed an investigational drug application with the FDA to modify the current license. Filing an IND application to change the AVA's licensing requirements demonstrates an acknowledgment that the vaccine possesses IND status. ${ }^{149}$

Additionally, the DOD has made a policy of changing the dosage schedule to remedy shortages of AVA..$^{150}$ DOD policy now allows any soldier who began the initial shot sequence, but failed to complete the sequence approved by the FDA, to finish the inoculations where the

144. Indeed, a statement on the House Reform Committee website encourages vaccinated members to write to the committee if they were vaccinated against anthrax: "If you are a member of the Armed Services and you've had an experience with the Anthrax vaccine, either good or bad, we want to hear from you. Please send your confidential email to anthrax@mail.house.gov. Your identity will not be revealed." United States House of Representatives Committee on Government Reform, at http://www.house.gov/reform (last visited Apr. 15, 2001) (on file with the Duke Law Journal).

145. Michels \& Smith, supra note 47, pt. III.B.2.

146. Id.

147. Id.

148. Id.

149. This is so because IND status occurs when a manufacturer seeks to conduct clinical tests of a medicine or biological agent. The IND status allows the manufacturer to conduct limited use of the product without FDA approval, as well as to transport the material across state lines without violating FDA regulations. 21 C.F.R. § 312 (2000) ("An investigational new drug . . may be shipped lawfully for the purpose of conducting clinical investigation.").

150. Supra notes $117-18$ and accompanying text. 
soldier left off, up to two years since the last shot. ${ }^{151}$ This is a clear offlabel, IND use of the vaccine, which normally requires an eighteenmonth inoculation schedule. ${ }^{152}$ Even the FDA approval letters, frequently used by the DOD to validate the legality of AVIP, state that the vaccine must be used in a manner consistent with its labeling. ${ }^{153}$

The FDA approval letters for the anthrax vaccine are illusory. Although the 1997 and 1999 letters written by FDA officials state that the vaccine is not an IND, FDA regulations provide that statements made in the letters have no legal effect on the IND status of the vaccine:

A statement made or advice provided by an FDA employee constitutes an advisory opinion only if it is issued in writing under this section. A statement or advice given by an FDA employee orally, or given in writing but not under this Section of $\$ 10.90$ is an informal communication that represents the best judgment of that employee at the time but does not constitute an advisory opinion, does not necessarily represent the formal position of the FDA, and does not bind or otherwise obligate or commit the agency to the views expressed. ${ }^{154}$

The 1997 and 1999 letters were not issued pursuant to this section and, as such, the letters do not commit the agency to the views expressed in the letters. ${ }^{155}$ In fact, the letters do not even constitute advisory opinions. The Supreme Court recently held that agency opinion letters are not entitled to deference by the Court. ${ }^{156}$ Rather, these types of letters are entitled to "respect" only to the extent that the letters' interpretations are persuasive. ${ }^{157}$ The DOD argues that the FDA letters validate its position that the AVA is not on IND status; however, since the letters are not agency-approved, do not constitute official agency opinions, and fail to take into account that the DOD is using AVA off-label, the letters are not persuasive. ${ }^{158}$ Thus, these letters have no legal bearing on the IND status of the anthrax vaccine.

\footnotetext{
151. Supra note 118 and accompanying text.

152. Id.

153. Supra note 68 and accompanying text.

154. 21 C.F.R. $\S 10.85(\mathrm{k})$ (2000) (emphasis added) (quoted in Michels \& Smith, supra note 47, at n.4).

155. Michels \& Smith, supra note 47, at n.4.

156. Christensen v. Harris County, 529 U.S. 576, 586-88 (2000).

157. Id.

158. See Michels Statement, supra note 74 (arguing for IND status).
} 
The DOD also has referred consistently to AVA as an IND in AVIP's files. The aforementioned 1995 examples of the Army's beginning the process of filing an IND application and requesting the license amendment briefing are two such incidents. ${ }^{159}$ Since the DOD has acknowledged tacitly that the vaccine is an IND, the presumption that an order to submit to vaccination is lawful should be rebutted, and military courts should analyze the lawfulness of the order and the safety and efficacy of the current anthrax vaccine.

\section{Critiquing Perry and Chadwell}

The three-sentence judicial determination in Perry v. Wesely stating that $\S 1107$ and Executive Order 13,139 are not applicable to a service member's refusal to take the anthrax vaccine does not withstand close scrutiny. ${ }^{160}$ First, even if Executive Order 13,139 is an "internal management" policy, the DOD is violating that policy, because the current vaccine is an IND. This logic leads to the conclusion that if something is an internal policy, it does not have to be followed and there is no accountability for refusing to follow it. Why have an internal management policy if it is ignored when convenient?

Second, and most importantly, the DOD expressly adopted the requirements of Executive Order 13,139 and 10 U.S.C. $§ 1107$ in a recently published DOD Directive. ${ }^{161}$ The directive explicitly states, "When using INDs for force health protection, DoD Components shall comply with 10 U.S.C 1107, E.O. 13139, and applicable FDA regulations." ${ }^{, 162}$ DOD Directive 6200.2 goes on to lay out a comprehensive scheme to effectuate the requirements of Executive Order 13,139 and 10 U.S.C. $\S 1107$ and specifically references both as authority. ${ }^{163}$ Thus, the Navy Court not only was engaging in a sloppy legal analysis by failing to analyze the directive, but its position is vitiated by the fact that the DOD expressly acknowledged that the law applies and has published a directive to enforce the statute and executive order for service members. ${ }^{164}$

159. Supra notes $145-49$ and accompanying text.

160. Perry v. Wesely, No. NMCM 200001397, 2000 WL 1775249, at*3 (N-M. Ct. Crim. App. Nov. 29, 2000).

161. Department of Defense Directive 6200.2, § 4.14 (Aug. 1, 2000).

162. Id.

163. Id.

164. John J. Michels, counsel for Major Sonnie Bates, commented:

When you see obviously smart people such as the Navy Court making foolish decisions that ignore DoD's own directives, then you look for another reason for the deci- 
The Chadwell decision can be distinguished because it involved entirely different circumstances than the anthrax vaccine refusal cases. In Chadwell, the issue was not the safety and efficacy of the vaccine; rather, it was about religious convictions against vaccines. ${ }^{165}$ The arguments are entirely different: one is based on a claim of freedom of religion and the other is based on federal statutes and executive orders requiring informed consent of subjects given an IND. The Chadwell court stated "on its face the order was legal and this fact is not contested by the appellant. It is only in the application of the order of the two accused that it is contended that constitutional rights are violated." ${ }^{, 166}$ Unlike in Chadwell, the issue here is whether the order was legal on its face, not in its application. If the vaccine is an IND, it is illegal to administer it without informed consent. If it is not an IND, the order is legal. Thus, the anthrax-refusal cases rest on an entirely different rationale than Chadwell.

\section{CONCLUSION}

The issue-after all the legal, medical, and political analysis-ultimately is one of trust. ${ }^{167}$ In its report on the anthrax vaccine, Congress noted that AVIP "lacks an essential element in a medical program: trust. However well-intentioned, the anthrax vaccine effort is viewed by many with suspicion. It is seen as another chapter in a long, unhappy history of military medical malfeasance in which the healing arts are corrupted to serve a lethal purpose." ${ }^{, 168}$ The consequences are severe if a service member who is ordered to take the vaccine loses trust in medicine, the vaccine, or government decisions. A breakdown in military order can, and perhaps will, occur. ${ }^{169}$

sion other than logic or jurisprudence. The decision reeks of pre-ordained outcome, and I think that it is impossible for a military court at any level to properly review this issue.

E-mail from Lieutenant Colonel John J. Michels, Jr., U.S. Air Force Reserve, to Randall D. Katz (Apr. 4, 2001) (on file with the Duke Law Journal). The author wishes to thank Lt. Col. John Michels for his assistance and guidance with this Note.

165. United States v. Chadwell, 36 C.M.R. 741, 747-48 (1965).

166. Id. at 748 .

167. See HoUSE REPORT, supra note 8, at 2 (noting that many members of the armed services do not share DOD's faith in the vaccine).

168. See id. at 45 .

169. The trust issue is exemplified by concerns of service members. See, e.g., Laura Laughlin, Shot to Hell: Mandatory Participation in the Military's Anthrax Vaccine Program Pushes Plunger on Medical Controversy, Phoenix New TIMes, Jan. 27, 2000 (giving the illustration of Joe, an Arizona Air National Guard Member, who struggled with the question of whether to submit to vaccination: "Joe says about 40 members of his Guard unit-including a 
GAO studies have shown that fear of the anthrax vaccine is causing service members to leave the armed forces at a significant rate. ${ }^{170}$ Those who do not leave face a difficult choice between submitting to vaccination, and possibly risking their health, or facing disciplinary action. Major Sonnie Bates and hundreds of others have decided the stakes were much too high for them to risk their healththey did not trust the government. ${ }^{171}$ Soldiers' fears about the safety and efficacy of the vaccine are underscored by the DOD's past failures to release information harmful to the Department. An example is the No Gun Ri massacre, in which American troops shot unarmed Korean civilians in the first month of the Korean War. ${ }^{172}$ The Pentagon denied the killings for decades, and admitted to the massacre only recently after an investigation was spurred by an Associated Press report detailing the incident. ${ }^{173}$ Similarly, the adverse safety and efficacy information on the anthrax vaccine may be the latest example of the Pentagon's deny-and-then-begrudgingly-admit policy. Service members have a right to be concerned. A recent editorial in the Air Force Times called for an end to mandatory anthrax vaccinations: "The anthrax vaccine inoculation program has sewn [sic] dissent in the ranks and added to the mistrust some troops harbor for their commanders. . . . [Q] uestions persist about the

couple of his friends-quit rather than begin the series of shots. And he expects more to follow when the vaccines are doled out to everyone."), available at http://www.phoenixnewtimes.com/ issues/2000-01-27/ feature.html (on file with the Duke Law Journal).

170. Supra note 22 and accompanying text.

171. Air Force Captain John Buck, the first military physician to refuse the anthrax vaccine, Funk, supra note 15 , at 16 , wrote, "[A]s a military physician, I have a responsibility to do all I can to protect the rights of the troops." E-mail from Captain John Buck to Randall D. Katz, supra note 15. Captain Buck refused to take the vaccine because of the lack of adequate information, production issues, and potential long-term health effects. Id. Captain Buck also expressed that he was concerned about the production facilities for the anthrax vaccine. Id. These facilities are also at the center of the anthrax controversy. Bioport, the maker of the vaccine, has a facility in Michigan that has a "checkered regulatory history." HOUSE REPORT, supra note 8, at 3.

172. See Joohee Cho \& Doug Struck, U.S. Statement on Killings Disappoints South Koreans, WASH. PosT, Jan. 12, 2001, at A18 (describing how Koreans regarded President Clinton's statement of regret for the incident as "incomplete and too late"); Roberto Suro \& Thomas E. Ricks, Clinton to Express Korean War Regret, WASH. PosT, Jan. 11, 2001, at A7 (noting that President Clinton plans to issue a written statement of regret for the incident).

173. Suro \& Ricks, supra note 172, at A7. The 2000 Pulitzer Prize-winning series of articles on the No Gun Ri Massacre was written by Charles Hanley et al., and can be found at The Pulitzer Prize Website. See Pulitzer Prize Winners: Bridge at No Gun Ri, The Pulitzer Board, at http://www.pulitzer.org/year/2000/investigative-reporting/works (last visited Apr. 5, 2001) (on file with the Duke Law Journal). 
.. [Q]uestions persist about the quality, efficacy, safety and legality of the shots." 174

Numerous pieces of legislation have been introduced regarding AVIP, with remedies ranging from halting the program to requiring informed consent. Three bills were before the 106th Congress. The first was H.R. 2548, the "Department of Defense Anthrax Vaccination Moratorium Act," which proposed suspending AVIP until the vaccine is determined to be safe. ${ }^{175}$ The "American Military Health Protection Act," H.R. 2543, would have made AVIP voluntary until the FDA approves a new vaccine or reduced dosage. ${ }^{176}$ Similar legislation, H.R. 3460, would have prohibited the DOD from waiving informed consent for an IND or a drug not approved for its applied use. ${ }^{177}$

Others outside the military and Congress are moving to halt the program. In fact, Connecticut Attorney General Richard Blumenthal recently wrote a letter to Secretary of Defense Donald Rumsfeld urging him to make AVIP voluntary or halt the program. ${ }^{178}$ Attorney General Blumenthal remarked in his letter, "Unfortunately, and directly contrary to law, the [vaccine] is being administered. . . . In effect, the military is forcing its personnel to serve as human guinea pigs for an unlicensed drug that has not been proven to be safe or effective." $" 179$

It is clear from the plethora of press reports, personal stories, and congressional testimony that the DOD needs to regain the trust of its service members with regard to anthrax vaccinations. ${ }^{180}$ If Congress halts the program on its own, the DOD will not regain the trust it has lost. The DOD should regain trust by making the system work: military judges should examine the merits of the cases and make a fair judicial evaluation, and the DOD should halt the program to conduct more research on the long-term health effects and the vaccine's effectiveness. Additionally, the DOD should cause the current vaccine to

174. Editorial, AIR FORCE TIMES, Jan. 8, 2001, at 44.

175. H.R. 2548, 106th Cong. §§ 3-4 (1999).

176. H.R. 2543, 106th Cong. $\$ 3$ (1999).

177. H.R. 3460, 106th Cong. § 2 (1999).

178. Letter from Richard Blumenthal, Attorney General, State of Connecticut, to Donald Rumsfeld, Secretary, U.S. Department of Defense 1 (Mar. 21, 2001) (on file with the Duke Law Journal). The United Kingdom has made its anthrax innoculation program voluntary. Id. at 14 .

179. Id. at 2 .

180. See supra notes 13-22 and accompanying text (describing concerns with the vaccination program). 
undergo the approval process for its use against inhalation anthrax. An unidentified DOD spokesman eloquently summarized the trust issue at a briefing on AVIP:

I think medicine is based on trust. If for whatever reason, in any individual's mind he loses trust in his medicine, in his doctor, or he loses trust in his government, then those sorts of feelings will fall on more fertile ground.... Our job is to regain that trust and make sure that our message is clear, that we are protecting our people, that we are doing everything we possibly can to make sure we are not harming them with the thing we give them to protect them. ${ }^{181}$

AVIP is analogous to "friendly fire" on American service members. Although the DOD certainly is not intentionally trying to harm its troops, and AVIP was born out of a genuine concern for American well-being and safety, the risks associated with the vaccine are largely unknown. The DOD must stop the friendly fire "shots" and regain service members' trust. ${ }^{182}$ The ultimate question, at the heart of the anthrax vaccination controversy, is whether friendly fire is more dangerous than enemy fire.

181. Michels \& Smith, supra note 47 (quoting an "Unidentified Defense Department Spokesman").

182. Maybe the problem is solving itself. Due to the manufacturer's problems producing the vaccine, the Pentagon has recently drastically cut back AVIP:

Under the change ... only troops that will serve in the Gulf for at least 30 days will receive the shot, [former] Pentagon spokesman Kenneth Bacon said. Forces deployed in South Korea, the only others now receiving the vaccine under a program curtailed to preserve scarce supplies, no longer will be vaccinated.

Pauline Jelinek, Anthrax Vaccine Program to Dwindle, AP ONLINE, Dec. 1, 2000, at 1, available at 2000 WL 30317307. This could be the DOD's opportunity for a graceful exit. 